\title{
An Experimental Investigation on Regulated and Unregulated Emissions of a Gasohol Fueled SI Engine with a Novel Three Way Catalytic Converter
}

\author{
Sathish Sharma Gunasekaran, Sugavaneswaran Manivannan, Prakash Ramakrishnan* \\ School of Mechanical Engineering, Vellore Institute of Technology, Vellore, Tamil Nadu 632014, India
}

Corresponding Author Email: prakash.ramakrishnan@vit.ac.in

https://doi.org/10.18280/jesa.530208

Received: 25 December 2019

Accepted: 2 February 2020

\section{Keywords:}

alternate fuels, gasohol, regulated and unregulated emissions, catalyst, conversion efficiency, three-way catalytic converter

\begin{abstract}
Alcohol blended with gasoline is generally termed as Gasohol. Gasohol fuel will reduce Carbon monoxide $(\mathrm{CO})$, Nitrous oxide $\left(\mathrm{NO}_{\mathrm{x}}\right)$, Hydro carbon $(\mathrm{HC})$ emissions and it will increase Carbon dioxide $\left(\mathrm{CO}_{2}\right)$. The regulated and unregulated emissions raise with increase in the Ethanol percentage of the fuel. For the reduction of both regulated and unregulated emissions new catalyst (Vanadium Pentoxide/Cobalt oxide) were coated over the metal substrate of the conventional catalytic converter. The performance of Vanadium Pentoxide/Cobalt oxide coated Three-way catalytic converter (TWC) and emissions test on a single cylinder four stroke petrol engine was conducted on the both regulated and unregulated emissions. The recorded emissions results were compared with conventional and Vanadium Pentoxide/Cobalt oxide coated catalytic converter. The experimental results suggest that Vanadium Pentoxide/Cobalt oxide coated catalytic converter reduces $55 \%, 38 \%$ and $45 \%$ of $\mathrm{HC}, \mathrm{CO}$ and $\mathrm{NO}_{\mathrm{x}}$ respectively. The reduction in unregulated emissions like acetaldehyde, acrolein, propionaldehyde and paraldehyde was reduced by $51 \%, 48 \%, 44 \%$ and $70 \%$ due to Three-way catalytic converter respectively.
\end{abstract}

\section{INTRODUCTION}

The progressive stringing norms on the poisonous exhaust gases that are emitted from the Internal Combustion (IC) engines, an increase in the cost of gasoline, and attention to improve the air quality of exhaust gas has expanded the researcher for utilizing gasohol as an alternative fuel. Also, the depletion of the non-renewable energy source is decreasing day by day. As indicated, the petroleum product will be available until 41, 63 and 218 years for oil, gaseous petrol and coal respectively [1-3]. The expanding automobiles and industrialization of the world have created a shortage of crude oils for consistent supply. The cost of crude oil is also getting higher consistently. This environment created a demand for a non-renewable energy source. Among these alternate fuels like biofuels, biogas, biodiesel and alcohol, alcohol is all the most appealing and promising elective fuels because of its storeroom, accessibility, and easy storage. Heavy weight is required to utilize biogas in the vehicle and it also has to face leakage of biogas which may cause an issue. Biodiesel from edible source may make a shortage of circumstance supply sustenance for the people. The utilization of non-palatable oil as biofuel sources require enormous scale development that may cause a decline in sustenance crops [4]. The greatest challenges faced by today's automobile industries are to find out the alternate fuels for generating the power. Gasohol fuels can be utilized with lesser or no modifications in the presentday gasoline IC engines [5]. Alcohols, for example, Ethanol and Methanol blends are utilized as an alternate fuel in different IC engines [6, 7]. Ethanol has been acknowledged as an elective fuel for the past 35 years in Brazil [8, 9]. In1970, Methanol blends was utilized as an alternate fuel during the oil emergency. The mixing of Methanol with oil was additionally utilized in various European nations in 1980 and 1990. The two alcohols (Ethanol and Methanol) will be utilized as alternate fuels in unadulterated structure or through mixing with regular gasoline fuel $[10,11]$.

Ethanol has greater octane number when compared with gasoline, and it has $34.7 \%$ of oxygen by weight. At the point the ethanol blends with gasoline will increases the oxygen content in the fuel blend, hence promotes complete combustion and decreases the emissions of $\mathrm{HC}$ and $\mathrm{CO}$. Gasohol fuel blends have been generally utilized in SI engines as a major alternate fuel. The SI exhaust emissions and engine performance on various gasohol blends have been examined by numerous scientists. Yucesu et al. [12] uses gasoline and ethanol blends in a SI engine and found that mixing of gasoline with ethanol slightly increases the brake torque and reduces $\mathrm{CO}$ and $\mathrm{HC}$ emissions. Hsieh et al. [13] analyzed the performance characteristics of the engine and emissions of a SI engine using ethanol blends as fuel at different mixtures. The result show, that fuel consumption and engine torque have increased with the increase in ethanol percentage it was also evident that $\mathrm{CO}$ and $\mathrm{HC}$ emissions reduced significantly with increase in of ethanol portion. $\mathrm{NO}_{\mathrm{x}}$ depended primarily on the operating condition of the engine instead of the ethanol content. Al- Hasan [14] revealed that increase in ethanol portion will also leads to increase in brake power, brake thermal efficiency, and volumetric efficiency. Moreover, the utilization of ethanol-fuel blend will reduce the $\mathrm{CO}, \mathrm{HC}$, and $\mathrm{NO}_{\mathrm{x}}$ exhaust emissions. He et al. [15] said that the ethanol blend reduces tailpipe $\mathrm{CO}, \mathrm{HC}$, and $\mathrm{NO}_{\mathrm{x}}$ emissions. Wu et al. [16] detailed that regulated emissions like $\mathrm{CO}$ and $\mathrm{HC}$ were decreased with the rise in percentage of ethanol in the blended fuel. Graham et al. [17] researched the outflows of gasoline engine and revealed that working on E10 mixes (with 10 percentage of 
ethanol by volume) resulted in reductions of $\mathrm{CO}$ emissions by (16 percent) and $\mathrm{HC}$ emissions by ( 9 percent), an increase in the acetaldehyde emissions was recorded by (108 percent), and no major change in $\mathrm{NO}_{\mathrm{x}}$ emissions was observed. At present, there are lot of research going on for unregulated emissions, for example formaldehyde, acetaldehyde, and so forth, which are very unsafe to humans. Based on the literature study, it gives the idea that ethanol blends can be utilized successfully in Gasoline engine with slight or zero changes in Gasoline engine. Generally, the past researchers have concentrated on engine performance and $\mathrm{CO}, \mathrm{HC}$, and $\mathrm{NO}_{\mathrm{x}}$ emissions only, the unregulated emissions and their impacts is not yet explored in detail. In this investigation the regulated and unregulated emissions like acetaldehyde, and formaldehyde using gasohol as fuel in SI engine was studied. The conversion efficiency of the TWC and exhaust emissions characteristics were studied in a single cylinder four stroke SI engine fueled with gasoline and ethanol blends at different load conditions. The emission level of the $\mathrm{CO}, \mathrm{HC}$, and $\mathrm{NO}_{\mathrm{x}}$ was estimated by AVL di gas 444 analyzer, which had a banner intensifier for piezo information is utilized to detect the properties like $\mathrm{CO}, \mathrm{CO}_{2}$, $\mathrm{HC}, \mathrm{NO}_{\mathrm{x}}$. The unregulated emissions were estimated by a volatile organic compound (VOC) analyzer (Po check Tiger model) works with the Photo ionization detector (PID). It gives fast and precise information of unregulated emissions. The instrument utilized in this examination for estimating unregulated emanations is fit for estimating in an excess of 750 unregulated emissions. In this work, the load conditions were varied as $0 \%, 20 \%, 40 \%, 60 \%, 80 \%$ and $100 \%$ motor speed were maintained at rated speed. This was attempted so the regulated and unregulated emissions emission qualities could be obviously defined and the impact of variables such as ethanol part, exhaust temperature, and engine operating conditions on the single-cylinder four-stroke SI engine explained in brief.

Also, there isn't much research in replacing the precious metal catalysts used in the catalytic converters using various other metal catalysts that would perform efficiently and also reduce the production cost of the catalytic converters. In order to reduce the cost of conventionally produced catalytic converter, in which commonly used catalyst are rare earth metals (platinum, palladium, rhodium) these are replaced by cobalt oxide and vanadium pentoxide in this research work. The newly coated catalytic converter was fixed at the end of exhaust pipe and its conversion efficiency was also experimented. The experiments were conducted on a singlecylinder four-stroke SI engine using gasohol (gasoline + methanol) blends with three different mixtures such as $0 \%$ (E0), 10\% (E10), and 20\% (E20) and the TWC performance and emission characteristics were recorded.

In methodology section, the catalysts properties, sol-gel preparation and coating technique are explained briefly. In the experimentation section, the experimental setup and the components involved in the setup are explained. At last in the result and discussion section, the results obtained are elaborated and discussed. The key findings of the present investigation are mentioned in the conclusion section.

\section{METHODOLOGY}

\subsection{Sol-gel preparation and coating technique}

2.1.1 Vanadium pentoxide

Vanadium Pentoxide is an inorganic compound with the chemical formula $\mathrm{V}_{2} \mathrm{O}_{5}$. It is usually found in brown or yellow solid structure. It has high oxidation state and thus it serves as a great oxidation agent. Vanadium pentoxide has great thermal stability with a melting point of about $690^{\circ} \mathrm{C}$. Thus, with the high oxidation state which makes it a great oxidizing agent and the thermal stability which would help it work in the high temperature conditions of a Monolith helps us choose it as our Oxidation Catalyst for our Monolith.

\subsubsection{Cobalt oxide}

The pure cobalt oxide is chosen as our reduction catalyst [18]. It is an inorganic compound which appears as a greyish or black powder. Its surface properties make it a preferred catalyst for reducing of $\mathrm{NO}_{\mathrm{x}}$ emissions.

$10 \mathrm{mg}$ of Aluminum Nitrate was dissolved along with $2 \mathrm{mg}$ of Citric acid in a $150 \mathrm{ml}$ of Ethanol the solution is mixed for 2 hours after which $2 \mathrm{mg}$ of Cobalt Oxide and $2 \mathrm{mg}$ of Vanadium pentoxide are dissolved in the prepared solution. Now the solution is heated until it reaches $1 / 3^{\text {rd }}$ of its original volume. The remaining solution will be in a gel form which is known as sol gel and it is used for coating over the monolith. The catalytic converter is dipped into the solution for 10 minutes and sintered for 5 minutes same dipping and sintering is carried away for 5 times [19].

\section{EXPERIMENTATION}

The experiments were conducted on a single-cylinder fourstroke petrol engine with gasohol (gasoline + methanol) blends at three different mixtures such as $0 \%, 10 \%$, and $20 \%$ and the TWC performance and engine emission characteristics were recorded. The test engine is coupled along with the eddy current dynamometer. The fabricated and coated TWC was tested on a S.I Engine with $2.5 \mathrm{~kW}$ rated power detail description of the test engine is given in the Table 1. The schematic diagram of the experimental setup was shown in Figure 1.

Table 1. Technical specification of the test engine

\begin{tabular}{ccc}
\hline S. No & Engine & Specifications \\
\hline 1 & Type & Single cylinder four \\
stroke vertical Air cooled \\
2 & Rated power & $2.5 \mathrm{~kW}$ \\
3 & Rated speed & $3000 \mathrm{rpm}$ \\
4 & Bore diameter & $68 \mathrm{~mm}$ \\
5 & Stroke & $45 \mathrm{~mm}$ \\
6 & Compression ratio & $10.3: 1$ \\
\hline
\end{tabular}

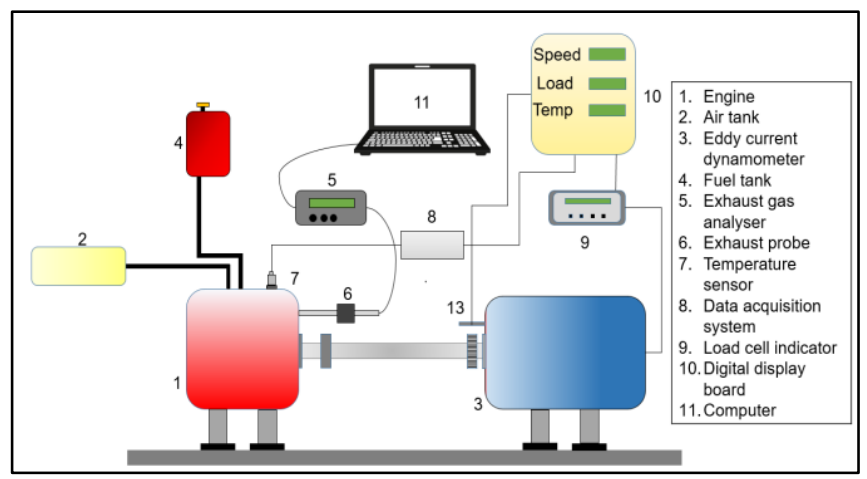

Figure 1. Schematic diagram of the experimental setup 
Thus, the TWC was to be modified for it to fitted at the exhaust outlet of the Engine. Now the AVL Exhaust Gas Analyzer and VOC analyzer (Po check Tiger model) works with the PID are used to find the amounts of emitted gases from the exhaust without the use of the TWC analyzer specification are specified in the Table 2. The Modified TWC is now attached onto the engine exhaust system and the engine runs on $100 \%$ gasoline. Now the AVL Analyzer's probe and VOC analyzer are inserted into the exhaust pipe and the Emission levels are noted. Now the both regulated and unregulated emissions were recorded and by comparing the values of emitted gases from both cases of with and without the use of the TWC, we derive to our required result and show how efficient our modified catalytic converter works. The TWC is also measured for its conversion efficiency on various loads on the Engine of no load $(0 \%), 20 \%, 40 \%, 60 \%, 80 \%$ and Full Load. Now same experiment is repeated with E10 blend (90\% gasoline and 10\% ethanol) and E20 bend (80\% gasoline and $20 \%$ ethanol) for different load conditions for both with and without TWC. Fuel properties of gasoline and the gasohol blends are tabulated in the Table 3. The fuel properties of the blends were taken from standard fuel testing laboratory.
Table 2. Instrument name, range, uncertainties and accuracy

\begin{tabular}{|c|c|c|c|c|}
\hline Quantity & Names & Range & Uncertainties & Accuracy \\
\hline $\begin{array}{l}\text { Oxides of } \\
\text { nitrogen }\end{array}$ & & $\begin{array}{c}0-6000 \\
(\mathrm{ppm})\end{array}$ & \pm 0.23 & \pm 10.2 \\
\hline $\begin{array}{l}\text { Hydro } \\
\text { carbons }\end{array}$ & $\begin{array}{c}\text { AVL 444N } \\
\text { Gas } \\
\text { analyser }\end{array}$ & $\begin{array}{c}0- \\
20000 \\
(\mathrm{ppm})\end{array}$ & \pm 0.21 & \pm 20.5 \\
\hline $\begin{array}{l}\text { Carbon } \\
\text { monoxide }\end{array}$ & & $\begin{array}{c}0-20 \\
(\%)\end{array}$ & \pm 0.153 & $\pm 0.024 \%$ \\
\hline $\begin{array}{l}\text { Smoke } \\
\text { opacity }\end{array}$ & $\begin{array}{l}\text { Opacity } \\
\text { meter }\end{array}$ & $\begin{array}{l}0-100 \\
(\%)\end{array}$ & \pm 1.12 & $\pm 1.2 \%$ \\
\hline $\begin{array}{l}\text { Exhaust } \\
\text { gas temp. }\end{array}$ & $\begin{array}{l}\text { Thermo } \\
\text { couple }\end{array}$ & $\begin{array}{c}0-1000 \\
\left({ }^{\circ} \mathrm{C}\right)\end{array}$ & \pm 0.21 & $\pm 1^{\circ} \mathrm{C}$ \\
\hline Speed & $\begin{array}{l}\text { Tacho } \\
\text { meter }\end{array}$ & $\begin{array}{c}0-9999 \\
(\mathrm{rpm})\end{array}$ & \pm 0.153 & $\pm 10 \mathrm{rpm}$ \\
\hline $\begin{array}{l}\text { Cylinder } \\
\text { pressure }\end{array}$ & $\begin{array}{l}\text { Pressure } \\
\text { pick up }\end{array}$ & $\begin{array}{c}0-250 \\
\text { (bar) }\end{array}$ & \pm 0.12 & $\begin{array}{c} \pm 0.12 \\
\text { bar }\end{array}$ \\
\hline $\begin{array}{l}\text { Crank } \\
\text { angle }\end{array}$ & Encoder & $0-360^{\circ}$ & \pm 0.21 & $\pm 1.2^{\circ} \mathrm{C}$ \\
\hline $\begin{array}{c}\text { Fuel } \\
\text { capacity }\end{array}$ & Burette & $\begin{array}{l}0-100 \\
(\mathrm{cc})\end{array}$ & \pm 1.24 & $\begin{array}{l} \pm 0.12 \\
(\mathrm{cc})\end{array}$ \\
\hline Time & Stopwatch & $\mathrm{Na}$ & \pm 0.25 & \pm 0.623 \\
\hline \multicolumn{5}{|c|}{$\begin{array}{c}\text { Total uncertainty } \\
\pm 3.2 \%\end{array}$} \\
\hline
\end{tabular}

Table 3. Properties of gasoline and gasohol blends

\begin{tabular}{cccc}
\hline Properties & $\begin{array}{c}\mathbf{1 0 0 \%} \text { Gasoline } \\
\text { (E0) }\end{array}$ & $\begin{array}{c}\mathbf{9 0 \%} \text { gasoline + 10\% } \\
\text { ethanol (E10) }\end{array}$ & $\begin{array}{c}\mathbf{8 0 \%} \text { gasoline + 20\% } \\
\text { ethanol (E20) }\end{array}$ \\
\hline Calorific Value $(\mathrm{MJ} / \mathrm{L})$ & 34.84 & 33.19 & 32.91 \\
Octane Number & 93.2 & 97.1 & 100.4 \\
Flash point ${ }^{\circ} \mathrm{C}$ & - & - & 29.2 \\
Fire point ${ }^{\circ} \mathrm{C}$ & 25.0 & 29.0 & 30.0 \\
Cloud point ${ }^{\circ} \mathrm{C}$ & -22.0 & $>8$ & $>8$ \\
Density $(\mathrm{kg} / \mathrm{L}) @ 15.6^{\circ} \mathrm{C}$ & 0.7400 & 0.7396 & 0.7541 \\
Kinematic Viscosity $\left(\mathrm{mm}^{2} / \mathrm{sec}\right) @ 30^{\circ} \mathrm{C}$ & 0.4872 & 0.5383 & 0.6007 \\
\hline
\end{tabular}

\section{RESULTS AND DISCUSSION}

\subsection{Performance characterization}

Fuel efficiency of the engine is one of the greatest attributes that must be improved and it is discussed by analyzing the Brake Specific Fuel Consumption (BSFC). Mass of fuel used for generating a unit power is called BSFC. Brake Specific Energy Consumption (BSEC) is the ratio of energy obtained by burning fuel for an hour to the brake power. The assessment of BSEC is portrayed in Figure 2 which shows the fuel economy for assessing the exhibition of gasoline and gasohol fuels. Ethanol with wide combustibility limits when mixed with fuel makes the engine to perform in lean mixture conditions. BSEC of ethanol mix E10 is always slightly lesser than E0 blends at greater load condition. Further it was seen that proportion with E10 shows lesser BSEC when compared with E0 and E20. While for the E20 blend the BSEC values were slightly higher than E10 blend because of the decrease in combustion temperature which occurred due to lesser available fuel energy. A $10 \%$ drop in calorific qualities implies more fuel utilization for E20 blend.

For a consistent speed engine, the Brake Thermal Efficiency (BTE) indicates how well heat produced in engine is changed into useful work. The BTE lay on the fuel consumed, power generated and fuel energy. The analysis of the BTE for various blends along with different brake power was done in Figure 3.

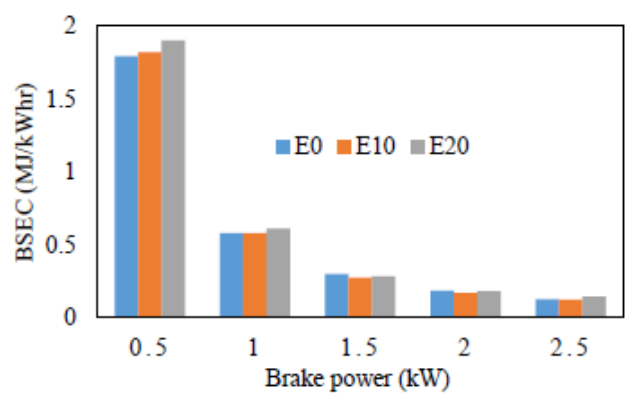

Figure 2. Variation of BSEC with Brake Power

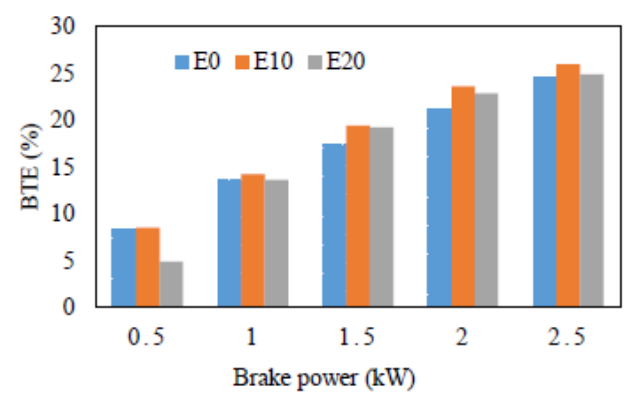

Figure 3. Variation of BTE along with Brake power

It is seen that with increment in brake power, the BTE increments for all test mixes. Increment in BTE with ethanol 
mix is essentially due to high LHV when compared with gasoline [20]. The enormous increase of LHV helps improving the amount of fuel vapor in the working charge during compression in homogeneous blend which leads to improvement in combustion inside the cylinder and decreases the heat loss to walls. While for the E20 increment in BSFC is the principle purpose behind drop in $\mathrm{BP}$ and furthermore in BTE.

\subsection{Useful energy}

Useful energy is which actually used for work neglecting the other losses. From the Figure 4, it is obvious that the useful work increases along with increase in load. The valuable work for the E10 and E20 blends is seen as higher than gasoline E0 blend. This might be because of productive burning of fuels and cooling impact of ethanol. Comparative outcome has been accounted for by Ajav et al. [21].

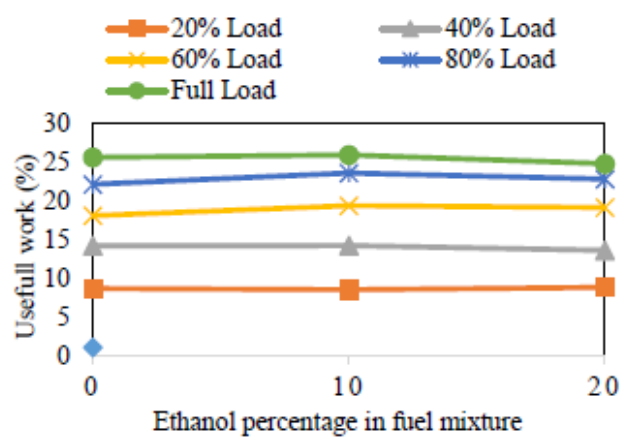

Figure 4. Variation of Useful energy for gasoline and ethanol blends at different loads

\subsection{Regulated emissions}

\subsubsection{Hydrocarbon emissions}

$\mathrm{HC}$ emission originates from the unburned or incomplete consumption of the fuel, oil film, and deposits. From Figure 5, it is evident that reduction in $\mathrm{HC}$ emission was seen due to the increase in ethanol mixture to the fuel. The ethanol blend carries the oxygen content along with it, which results in more complete combustion hence HC emissions were reduced [14]. $\mathrm{HC}$ emission before the TWC are shown in Figure 5 while comparing with the $\mathrm{E} 0$ blend, $\mathrm{HC}$ emissions were decreased by $12-21$ percent and 18-31 percent for the E10 and E20 blends. As found in Figure 5, $\mathrm{HC}$ emissions are altogether brought down by the TWC, the conversion efficiencies are at an average of 55 percent for E0, E10, and E20 blends.

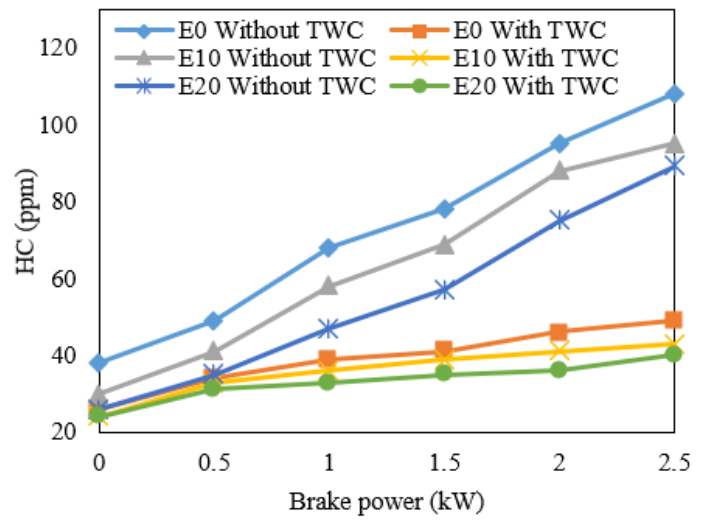

Figure 5. Variation of HC emissions with brake power

\subsubsection{Carbon monoxide emissions}

During the combustion process $\mathrm{CO}$ produces as an intermediate product. The percentage of $\mathrm{CO}$ presences significantly relies upon the working conditions of the air/fuel mixture. $\mathrm{CO}$ is continuously present in the exhaust gas even at lean mixture operating conditions. Figure 6 indicates the $\mathrm{CO}$ emissions for E0, E10 and E20 blends and compared with both with and without TWC. In which $\mathrm{CO}$ emissions were reduced by 5 percent and 28 percent for E10 and E20 blends when compared with E0 blend. The decrease of $\mathrm{CO}$ emissions occurs due to increased combustibility range and oxygen content. Figure 6 demonstrates the TWC conversion efficiencies of $\mathrm{CO}$ emissions are around 35 percent.

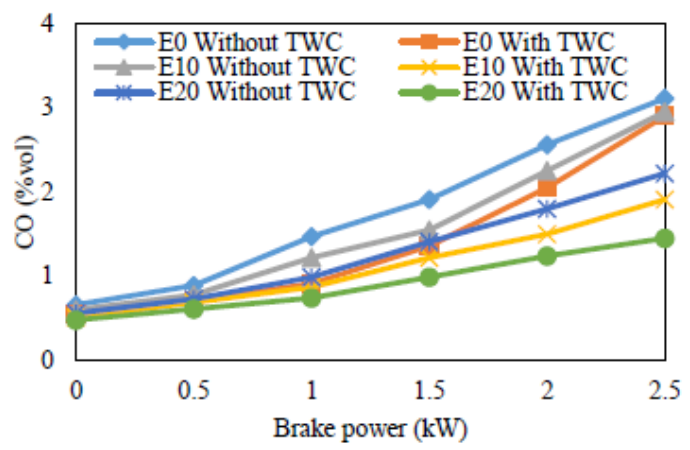

Figure 6. Variation of brake power with $\mathrm{CO}$ emissions

\subsubsection{Nitrogen oxide emission}

$\mathrm{NO}_{\mathrm{x}}$ discharge relies upon oxygen content, engine operating temperature, and the time taken for the exhaust to go out of the combustion chamber [15]. Figure 7, shows that before the TWC the $\mathrm{NO}_{\mathrm{x}}$ emissions, where tends to be seen that more the ethanol blend, lower the $\mathrm{NO}_{\mathrm{x}}$ emissions. Due to the ethanol's high latent heat of vaporisation there was a decrease in engine peak temperature which is also the reason for reduction in $\mathrm{NO}_{\mathrm{x}}$. The reductions in $\mathrm{NO}_{\mathrm{x}}$ emission were around 12 and 38 percent for the E10 and E20 blends when compared with E0 blend. Figure 7 also, demonstrates the $\mathrm{NO}_{\mathrm{x}}$ emissions after the TWC, $\mathrm{NO}_{\mathrm{x}}$ emissions are essentially brought down by TWC and its conversion efficiencies are around 48 percent for E0, E10, and E20 blends.

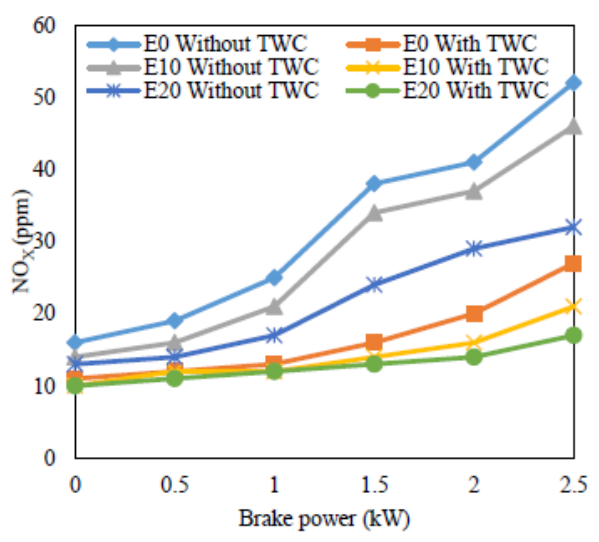

Figure 7. Variation of brake power with NOx emissions

\subsection{Unregulated emissions}

Unregulated emissions discharge relies on the alcohol presence and its percentage in the gasoline. From the Figures $8,9,10$ and 11 show the clear idea of emissions of unregulated 
emissions such as acetaldehyde, acrolein, propionaldehyde and paraldehyde respectively. It is evident from Figures 8-11 that emissions level was minimum for E0 blends and it keeps on increasing with increase ethanol content with gasoline which proves that unregulated emissions depend only on ethanol addition.

From Figures 8-11, it is also evident that after fixing TWC there was a considerable reduction in emission level for all unregulated emissions. The emissions level of all unregulated emissions was maintained at minimum and uniform level irrespective of variation in ethanol content and brake power. It was found that acetaldehyde, acrolein, propionaldehyde and paraldehyde was reduced by $51 \%, 48 \%, 44 \%$ and $70 \%$ due to TWC.

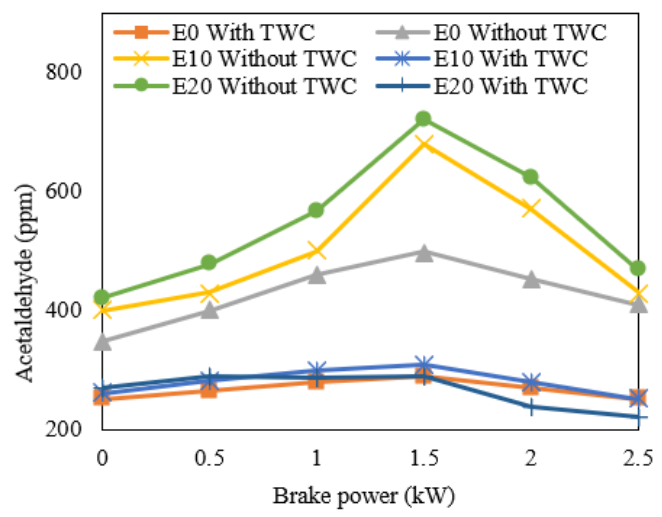

Figure 8. Variation of brake power with acetaldehyde emissions

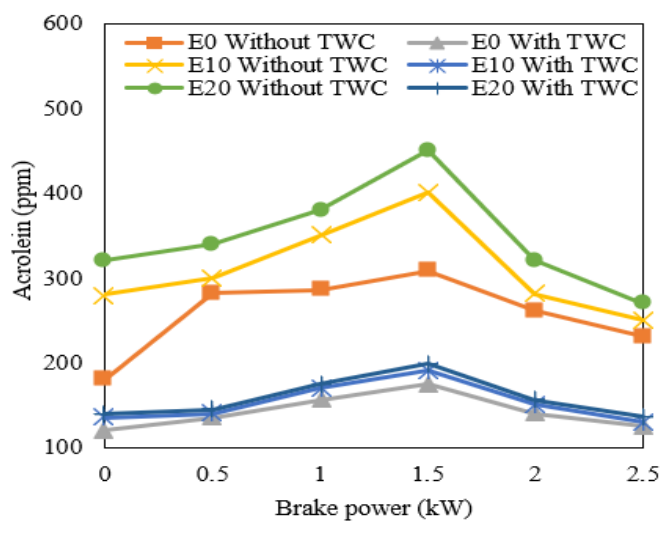

Figure 9. Variation of brake power with Acrolein emissions

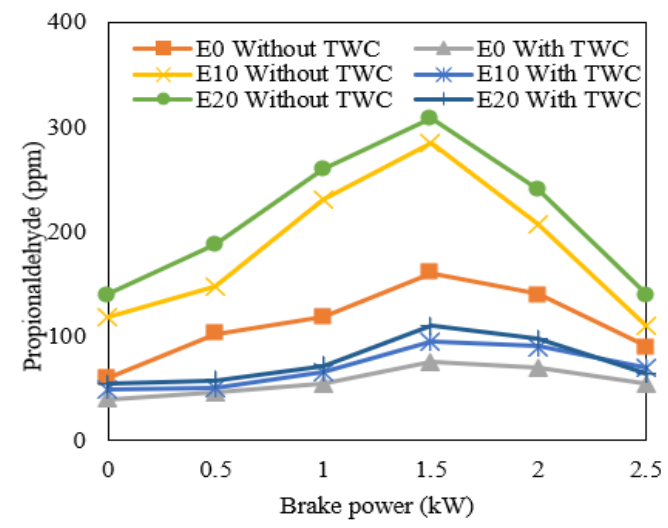

Figure 10. Variation of brake power with Propionaldehyde emissions

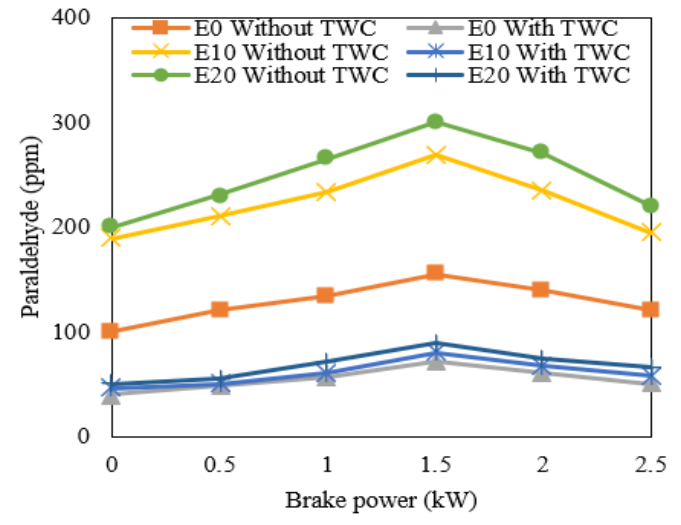

Figure 11. Variation of brake power with paraldehyde emissions

\section{CONCLUSION}

Gasohol fuels are considered as one among the prime alternative fuel for the petrol engines. In this current study, it's been discussed the possibilities of usage of the ethanol blends as an alternate fuel, without doing any modification in the petrol engine setup. Also, the major unregulated emissions from the petrol engine were quantified. A study on the performance of TWC, and engine exhaust emissions (both regulated and unregulated) using gasohol (gasoline + methanol) blends in three different ratios such as E0, E10, and E20 was done and following conclusions were made from the study.

- The regulated emissions $\mathrm{HC}, \mathrm{CO}$ and NOx keeps on decreasing with increase in ethanol fraction in gasoline. The TWC conversion efficiencies were 55\%, 38\% and $45 \%$ for $\mathrm{HC}, \mathrm{CO}$ and NOx respectively.

- The unregulated emissions like acetaldehyde, acrolein, propionaldehyde and paraldehyde was reduced by $51 \%$, $48 \%, 44 \%$ and $70 \%$ due to TWC respectively.

- It was also verified that there was an increase in the conversion efficiencies by $31 \%, 33 \%, 48 \%$ and $47 \%$ in acetaldehyde, acrolein, propionaldehyde and paraldehyde respectively with modified TWC.

\section{ACKNOWLEDGMENT}

The authors would like to acknowledge the assistance provided by the Science and Engineering Research Board, Department of Science and Technology, Government of India (Grant No. ECR/2016/001972, dated 22 March 2017).

\section{REFERENCES}

[1] Kessel, D.G. (2000). Global warming-facts assessment counter measures. Journal of Petroleum Science and Engineering, 26(1): 157-168. https://doi.org/10.1016/S0920-4105(00)00030-9

[2] Goldemberg, J., Johansson, T.B., Reddy, A.K.N., Williams, R.H. (2001). Energy for the new millennium. Ambio. J Hum Environ, 30(6): 330-337. https://doi.org/10.1579/0044-7447-30.6.330

[3] Gilbert, R., Peri, A. (2005). Energy and transport futures. 
Prepared for the National round table on the Environment and the economy. University of Calgary, 1-96.

[4] Imran, A., Varman, M., Masjuki, H.H., Kalam, M.A. (2013). Review on alcohol fumigation on diesel engine available alternative dual fuel technology for satisfactory engine performance and reduction of environment concerning emission. Renewable and Sustainable Energy Reviews, 26(1): 739-751. https://doi.org/10.1016/j.rser.2013.05.070

[5] Mughal, H.U., Bhutta, M.M.A., Athar, M., Shahid, E.M., Ehsan, M.S. (2012). The alternative fuels for four stroke compression ignition engines performance analysis. Transactions of Mechanical Engineering, 36(2): 155-164.

[6] Sampaio, M.R., Rosa, L.P., Agosto, M.D.A. (2008). Ethanol-electric propulsion as a sustainable technological alternative for urban buses in Brazil. Renewable and Sustainable Energy Reviews, 11(7): 1514-1529. https://doi.org/10.1016/j.rser.2005.11.007

[7] Mak, F.K. (1985). A study of the economics of alcoholgasoline blend production. Energy, 10(9): 1061-1073. https://doi.org/10.1016/0360-5442(85)90131-8

[8] Rosillo-Calle, F., Cortez, L.A.B. (1998). Towards Pro Al cool IIa review of the Brazilian bioethanol programe. Biomass Bioenergy, 14(2): 115-124. https://doi.org/10.1016/S0961-9534(97)10020-4

[9] Delgado, R.C.O.B., Araujo, A.S., Fernandes, V.J. (2007). Properties of Brazilian gasoline mixed with hydrated Ethanol for flex fuel technology. Fuel Processing Technology, 88(4): 365-368. https://doi.org/10.1016/j.fuproc.2006.10.010

[10] Kisenyi, J.M., Savage, C.A., Simmoiids, A.C. (1994). The impact of oxygenates on exhaust emissions of six European cars. SAE Technical Paper. https://doi.org/10.4271/940929

[11] Bayraktar, H. (2008). An experimental study on the performance parameters of an experimental CI engine fuelled with - methanol-do decanol blends. Fuel, 87(2): 158-164. https://doi.org/ 10.1016/j.fuel.2007.04.021

[12] Yucesu, H.S., Topgul, T., Cxinar, C., Okur, M. (2006). Effects of ethanol-gasoline blends on engine performance and exhaust emissions in different compression ratios. Applied Thermal Engineering, 26(17): $2272-2278$ https://doi.org/10.1016/j.applthermaleng.2006.03.006

[13] Hsieh, W.D., Chen, R.H., Wu, T.L., Lin, T.H. (2002).
Engine performance and pollutant emission of an SI engine using ethanol-gasoline blended fuels. Atmospheric Environment, 36(3): 403-410. https://doi.org/10.1016/S1352-2310(01)00508-8

[14] Al-Hasan, M. (2003). Effect of ethanol-unleaded gasoline blends on engine performance and exhaust emissions. Energy Conversion Management, 44(9): $1547-1561$ https://doi.org/10.1016/S01968904(02)00166-8

[15] He, B.Q., Wang, J.X., Hao, J.M., Yan, X.G., Xiao, J.H. (2003). A study on emission characteristics of an EFI engine with ethanol blended gasoline fuels. Atmospheric Environment, $37(7)$ : 949-957. https://doi.org/10.1016/S1352-2310(02)00973-1

[16] Wu, C.W., Chen, R.H., Pu, J.Y., Lin, T.H. (2004). The influence of air-fuel ratio on engine performance and pollutant emission of an SI engine using ethanolgasoline blended fuels. Atmospheric Environment, 38(40): 7093-7100. https://doi.org/10.1016/j.atmosenv.2004.01.058

[17] Graham, L.A., Belisle, S.L., Baas, C.L. (2008). Emissions from light duty gasoline vehicles operating on low blend ethanol gasoline and E85. Atmospheric Environment, $\quad 42(19)$ : 4498-4516. https://doi.org/10.1016/j.atmosenv.2008.01.061

[18] Kalam, M.A., Masjuki, H.H., Redzuan, M., Mahlia, T.M.I., Fuad, M.A., Mohibah, M., Halim, K.H., Ishak, A., Khair, M., Shahrir, A., Yusoff, A. (2009). Development and test of a new cat-alytic converter for natural gas fuelled engine. Sadhana, 34(3): 467-481.

[19] Sathish Sharma, G., Sugavaneswaran, M., Vijayalakshmi, U., Prakash, R. (2019). Influence of $\gamma$-alumina coating on surface properties of direct metal laser sintered $316 \mathrm{~L}$ stainless steel. Ceramics International, 45(10): 1345613463. https://doi.org/10.1016/j.ceramint.2019.04.046

[20] Irimescu, A. (2012). Performance and fuel conversion efficiency of a spark ignition engine fueled with isobutanol. Applied Energy, 96: 477-483. https://doi.org/10.1016/j.apenergy.2012.03.012

[21] Ajav, E.A., Singh, B., Bhattacharya, T.K. (2000). Thermal balance of a single cylinder diesel engine operating on alternative fuels. Energy Conversvation Managment, 41(14): 1533-1541. https://doi.org/10.1016/S0196-8904(99)00175-2 